\title{
PENINGKATAN SUMBER DAYA MASYARAKAT DESA MELALUI BINAAN PUSAT KEGIATAN BELAJAR MASYARAKAT
}

\author{
IMPROVING RESOURCES OF VILLAGE \\ COMMUNITY IN COMMUNITY LEARNING ACHIEVEMENT ACTIVITIES
}

\author{
${ }^{1)}$ Vethy Octaviani, ${ }^{2}$ Sri Narti, ${ }^{3}$ Syisva Nurwita \\ ${ }^{1,2}$ Fakultas Ilmu-Ilmu Sosial, ${ }^{3}$ Fakultas Keguruan dan Ilmu Pendidikan, \\ Universitas Dehasen Bengkulu \\ Jl. Meranti Raya No. 32 Sawah Lebar Kota Bengkulu \\ email : vethyoc@yahoo.co.id
}

\begin{abstract}
ABSTRAK
Minimnya produktifitas dan aktifitas perekonomian yang dilakukan oleh masyarakat disebabkan oleh kurangnya pengetahuan dan keterampilan yang dimiliki. Maka dari itu Pusat Kegiatan Belajar Masyarakat (PKBM) dibentuk sebagai sarana pendidikan berbasis masyarakat. PKBM Alena Smart School di Desa Tebat Monok dan PKBM Az-Zahir di Desa Talang Karet adalah dua diantara beberapa PKBM yang ada di Kabupaten Kepahiang. Tim PKM bersama kedua PKBM sebagai mitra melakukan upaya peningkatan keterampilan masyarakat dan peningkatan layanan pendidikan yang dilakukan melalui metode kegiatan pelatihan dan pendampingan bertujuan membantu meningkatkan kualitas dibidang produksi, manajemen, dan pemasaran dengan harapan tercapainya peningkatan perekonomian dan pendidikan yang berujung pada peningkatan kesejahteraan masyarakat di Desa Tebat Monok dan Desa Talang Karet. Hasil kegiatan yang telah dicapai adalah terbentuknya industri kecil yang dikelola oleh masyarakat desa Tebat Monok dalam binaan PKBM Alena Smart School yang difokuskan pada pembuatan handycraft dan handmade dengan merk dagang Tebat Monok Thonksys Galery And Craft. Sedangkan untuk masyarakat desa Talang Karet, usaha difokuskan pada makanan olahan dengan merk dagang Talang Karet Thonksys Cake's. Agar usaha dapat berkelanjutan, juga dilakukan pelatihan dan pendampingan dibidang manajemen untuk administrasi dan untuk kegiatan pemasaran yang dilakukan secara langsung dengan membuat pajangan di PKBM dan juga promosi melalui media sosial instagram. Selain itu, dalam kegiatan PKM juga dilakukan upaya peningkatan pelayanan bidang pendidikan di kedua PKBM sehingga kegiatan pendidikan kesetaraan Paket A,B, dan $C$ di PKBM Alena Smart School serta bimbingan belajar di PKBM Az-Zahir menjadi lebih nyaman, dimana juga didukung dengan adanya Taman Bacaan Masyarakat.
\end{abstract}

Kata Kunci : Pusat Kegiatan Belajar Masyarakat, Karet, Industri Kecil, Pelayanan Pendidikan

\section{ABSTRACT}

The lack of productivity and economic activity carried out by the community is caused by the lack of knowledge and skills possessed. Thus the Community Learning Activity Center (PKBM) was established as a community-based education tool. PKBM Alena Smart School in Tebat Monok Village and PKBM Az-Zahir in Talang Karet Village are two of several PKBM in Kepahiang Regency. PKM team and both of PKBM are together as partners make efforts to improve community skills and improvement of education services through training and advisory methods aimed to improve the quality of production, management and marketing with an expectation of achieving economic and educational improvements that lead to improving the welfare of Tebat Monok and Talang Karet Village Community. The result of the activity that has been achieved is the formation of a small industry managed by the community of Tebat Monok in the guidance of PKBM Alena Smart School which is focused on making handicraft and handmade with trademark of Tebat Monok Thonksys Galery And Craft. As for the Talang Karet village community, the business is focused on processed foods with trademarks of Talang Karet Thonksys Cake's. For the business able to run well, team also created the training and assistance in the field of management for administration and for direct marketing activities, team created the activity about to makin display in PKBM Location and created the promotion bay the sosial media instagram. Other than that, PKM activities are also carried out to improve education services in both PKBM so that the 
equalization of Package A, B, and C in PKBM Alena Smart School and guidance in PKBM Az-Zahir becomes more comfortable, which is also supported by the Park Community Reading.

Keywords: Community Learning Activity Center, Small Industry, Educational Services

Submited : 24 Mei $2018 \quad$ Revision : 7 Agustus $2018 \quad$ Accepted : 31 Oktober 2018

\section{PENDAHULUAN}

Keterbatasan lapangan kerja yang tersedia dan rendahnya tingkat pendidikan serta keterampilan masyarakat merupakan suatu masalah yang cukup rumit dalam proses pembangunan. Masyarakat di lapisan bawah semakin jauh dari pusat pelayanan pendidikan, sulit meningkatkan pengetahuan dan keterampilan, sehingga memperburuk struktur pertumbuhan negara berkembang (Sumpeno, 2009). Padahal sebagai negara yang sedang berkembang, Indonesia sangat potensial sekali dalam mengembangkan industri kecil, menengah bahkan industri besar. Hal ini, sesuai dengan amanah di dalam Undang-Undang No. 3 Tahun 2014 tentang perindustrian, dimana Pasal 14 menyebutkan peran pemerintah pusat dan/atau pemerintah daerah melakukan percepatan penyebaran dan pemerataan pembangunan industri ke seluruh wilayah negara kesatuan Republik Indonesia melalui perwilayahan industri (www.ppi.kemenperin.go.id)

Desa Tebat Monok dan Desa Talang Karet adalah desa yang terletak di wilayah Kecamatan Kepahiang Kabupaten Kepahiang Provinsi Bengkulu dengan jarak $\pm 60 \mathrm{~km}$ dan $\quad \pm 65 \mathrm{~km}$ dari Kota Bengkulu. Pertumbuhan industri di Desa Tebat Monok dan Desa Talang Karet masih sangat minim. Sumber penghasilan masyarakat rata-rata berasal dari kegiatan bertani, yang dilakukan oleh kaum lakilaki, sedangkan kaum perempuan mayoritas berperan sebagai ibu rumah tangga. Kondisi ini tentu saja berakibat pada rendahnya tingkat kesejahteraan masyarakat di kedua desa tersebut.

Dilihat dari kondisi wilayah dan masyarakat, Desa Tebat Monok dan Desa
Talang Karet mempunyai potensi yang sangat baik untuk dikembangkan. Letak desa yang berada di sepanjang jalan lintas Provinsi Bengkulu - Sumatera Selatan sangat potensial untuk dijadikan usaha yang bernilai ekonomi tinggi. Ditambah lagi Kabupaten Kepahiang terkenal dengan potensi hasil bumi seperti sayuran dan buahan yang dapat diolah menjadi makanan khas. Selain itu, Kabupaten Kepahiang juga memiliki potensi wisata yang sangat menarik seperti kebun teh, air terjun, taman bermain, dan lain sebagainya.

Namun, minimnya produktifitas dan aktifitas perekonomian yang dilakukan oleh masyarakat di Desa Tebat Monok dan Desa Talang Karet disebabkan oleh kurangnya pengetahuan dan keterampilan yang dimiliki. Masalah yang sama dalam pengembangan Usaha Kecil Menengah (UKM) antara lain masih lemahnya tingkat kemampuan, keterampilan, keahlian, dan manajemen. Lemahnya kemampuan manajemen ini mengakibatkan pengusaha kecil tidak mampu mengelola usahanya dengan baik (Kuncoro, 2006). Maka dari itu, pentingnya Pusat Kegiatan Belajar Masyarakat (PKBM) dibentuk sebagai sarana pendidikan berbasis masyarakat atau community based education yang bertujuan untuk menggali, menumbuhkan, mengembangkan dan memanfaatkan seluruh potensi yang ada di masyarakat itu sendiri sehingga dapat meningkatkan kualitas hidupnya (Sihombing, 2001). Hal serupa juga disampaikan dalam buku Membangun Pusat Kegiatan Belajar Masyarakat, bahwa kegiatan yang dilaksanakan di PKBM bertujuan untuk menyediakan pendidikan formal dan non formal bagi warga (Jalal, 2004). Sejalan dengan hal tersebut diatas, Pusat kegiatan 
Vethy Octaviani, Sri Narti, Syisva Nurwita

Peningkatan Sumber Daya Masyarakat Desa Melalui Binaan Pusat Kegiatan Belajar Masyarakat

Belajar Masyarakat (PKBM) merupakan satuan pendidikan non formal sebagai tempat pembelajaran dan sumber informasi yang dibentuk dan dikelola oleh masyarakat yang berorientasi pada pemberdayaan potensi setempat untuk meningkatkan pengetahuan, keterampilan, dan sikap masyarakat dalam bidang ekonomi, sosial dan budaya (Yulaelawati, 2010)

Pusat Kegiatan Belajar Masyarakat (PKBM) Alena Smart School di Desa Tebat Monok dan Pusat Kegiatan Belajar Masyarakat (PKBM) Az-Zahir di Desa Talang Karet adalah dua diantara beberapa PKBM yang ada di Kabupaten Kepahiang. Meskipun aktifitas masih belum optimal, melalui PKBM ini, masyarakat Desa Tebat Monok dan Desa Talang Karet dibentuk menjadi lebih kreatif dan inovatif dengan keterampilan seperti menjahit, membuat aksesoris layak jual (handmade), berkreasi dengan resep olahan makanan serta membuat handycraft. Selain itu juga, masyarakat yang putus sekolah dapat menjadi setara dengan mengikuti program kesetaraan Paket A, B, dan C. Pendidikan kesetaraan adalah salah satu satuan pendidikan pada jalur pendidikan non formal yang meliputi kelompok belajar program paket A setara SD/MI. Program paket B setara SMP,MTS, dan program paket $\mathrm{C}$ setara SMA/MA yang dapat diselenggarakan melalui Sanggar Kegiatan Belajar, Pusat Kegiatan Belajar Masyarakat, atau satuan sejenis lainnya (Undang-Undang No.20 Tahun 2003 Tentang Sistem Pendidikan Nasional Pasal 26 ayat 31 ). Selain itu juga terdapat bimbingan belajar bagi anak sekolah dan taman bacaan masyarakat

Tim PKM bersama mitra mengidentifikasi perlunya peningkatan layanan kependidikan dan peningkatan soft skill keterampilan masyarakat yang dilakukan melalui kegiatan pelatihan dan pendampingan atau istilah lainnya adalah capacity building yaitu pembangunan keterampilan (skill) dan kemampuan (capabilities) yang difasilitasi melalui penetapan kegiatan bantuan teknik, meliputi pendidikan dan pelatihan, bantuan teknik khusus (specific technical assistance) dan penguatan jaringan (Campobasso dan Davis, 2001). Dalam upaya mengembangkan potensi Pusat Kegiatan Belajar Masyarakat (PKBM) sebagai tempat dimana masyarakat dapat belajar dalam rangka meningkatkan pengetahuan dan keterampilan tentu saja memiliki permasalahan terutama terkait produksi, manajemen dan pemasaran. Dalam program kemitraan masyarakat ini akan merangkul 2 (dua) PKBM di Kabupaten Kepahiang yaitu PKBM Alena Smart School di Desa Tebat Monok dan PKBM Az-Zahir di Desa Talang Karet. Masing-masing mitra memiliki permasalahan yang dihadapi. Untuk mitra pertama yakni PKBM Alena Smart School memiliki beberapa permasalahan yaitu :

1. Dalam menjalankan program keterampilan masyarakat yaitu pembuatan handycraft dan handmade, permasalahan yang dihadapi PKBM Alena Smart School adalah peralatan untuk menjahit dan bahan baku pembuatan handycraft dan handmade masih kurang. Selain itu juga diperlukan pelatihan agar sehingga produk yang dihasilkan lebih variatif dan memiliki nilai jual. Permasalahan lain terkait dengan pemasaran yang hanya dilakukan di PKBM saja sehingga produk yang dihasilkan tidak dapat dikenal secara cepat oleh masyarakat luas karena hanya dari mulut ke mulut.

2. Dalam menjalankan program pendidikan kejar Paket A,B, dan C, permasalahan yang dihadapi adalah pelaksanaan program kesetaraaan paket A, B, dan C masih menumpang di Gedung SMPN 2 Kepahiang sehingga pemberian materi kurang optimal. Peranan PKBM sangat penting dalam mengurangi buta aksara, ditandai dengan banyaknya peserta dewasa yang mengikuti program Paket A, B, dan C (Irmawati, 2017) 
Sedangkan untuk mitra kedua yakni PKBM Az-Zahir juga memiliki beberapa permasalahan yang serupa yaitu :

1. Dalam menjalankan program keterampilan masyarakat yaitu pembuatan makanan olahan, PKBM Az-Zahir memiliki permasalahan yaitu perlu diadakan pelatihan agar produk yang dihasilkan lebih variatif. Selain itu pemasaran produk makanan olahan masih dilingkungan PKBM saja yaitu dititip di warung-warung sekitar PKBM.

2. Dalam menjalankan program bimbingan belajar, permasalahan yang dihadapi adalah ruangan belajar yang sangat sederhana sehingga tidak nyaman dalam proses belajar mengajar.

Permasalahan lain yang dihadapi PKBM terutama untuk mendukung kegiatan pendidikan yaitu keberadaan bahan bacaan yang masih sangat diperlukan. Namun koleksi bacaan yang dimiliki masih kurang hanya dari swadaya tiap PKBM sendiri dan ruang baca yang juga kurang nyaman. Maka diperlukan Taman Bacaan Masyarakat yang dapat digunakan oleh semua masyarakat untuk menambah pengetahuan. PKBM memiliki peranan yang sangat penting dalam menumbuhkan minat baca warga belajar (Sutisna et al, 2012)

Dari pemaparan di atas, tim PKM tertarik untuk membantu meningkatkan kualitas PKBM dibidang produksi, manajemen dan pemasaran serta kualitas dibidang pendidikan, dengan harapan tercapainya peningkatan perekonomian dan peningkatan pendidikan yang berujung pada peningkatan kesejahteraan masyarakat di Desa Tebat Monok dan Desa Talang Karet Kecamatan Kepahiang Kabupaten Kepahiang Provinsi Bengkulu.

\section{METODE}

Metode kegiatan ini adalah : a. Survei atau observasi lokasi mitra untuk memperkuat kegiatan riil apa saja yang perlu dilakukan terhadap kedua mitra

b. Evaluasi permasalahan berupa penentuan solusi yang ditawarkan dan kesepakatan bersama mitra agar adanya persamaan persepsi tentang kegiatan yang akan dilaksanakan.

c. Penyusunan materi dan kelengkapan peralatan untuk pelaksanaan kegiatan.

2. Tahap Pelatihan dan Pendampingan

a. Sosialisasi

Pelaksanaan kegiatan diawali pendekatan dengan masyarakat Desa Tebat Monok dan Desa Talang Karet khususnya kaum perempuan untuk mensinergikan kegiatan-kegiatan yang akan dilakukan berkaitan dengan peningkatan kesejahteraan masyarakat. Kegiatan ini diarahkan melalui proses sosialisasi tentang pentingnya keberadaan Pusat Kegiatan Belajar Masyarakat (PKBM) bagi masyarakat sehingga masyarakat termotivasi untuk mau mengembangkan potensi yang dimiliki dengan memanfaatkan sumber daya yang tersedia melalui wadah PKBM.

b. Pelatihan dan Pendampingan

1) Pelatihan, dilakukan terkait dengan keterampilan dan keahlian yang diperlukan. Dalam hal ini akan dilakukan pelatihan di PKBM untuk menghasilkan produk yang lebih kreatif dan berkualitas

2) Pendampingan, dilaksanakan dalam bentuk pendampingan aktifitas produksi mulai dari pengadaan bahan baku dan pengadaan peralatan, mendesain produk hingga pendampingan dalam sistem manajemen dan perluasan pemasaran. Selain itu pendampingan juga dilakukan dalam kegiatan pendidikan yaitu pelaksanaan kejar paket, bimbel, dan taman bacaan masyarakat yang nyaman dan berkualitas.

\section{Tahap Persiapan}


c. Tahap Evaluasi, dilakukan untuk melihat tingkat keberhasilan kegiatan mulai dari awal, proses, hingga capaian hasil kegiatan.

Partisipasi mitra dalam pelaksanaan proram ditunjukkan dengan adanya dukungan dan kesanggupan bekerjasama sebagai mitra dengan tim dari Universitas Dehasen dimana diwujudkan dalam pelaksanaan kegiatan yang dilakukan secara bersama-sama.

Kegiatan pelatihan produksi, manajemen, dan pemasaran di PKBM Alena Smart School dilaksanakan pada 17-29 Maret 2018 yang dihadiri oleh masyarakat desa Tebat Monok khususnya kaum perempuan sebanyak 25 Orang.

\section{HASIL DAN PEMBAHASAN}

\section{Pembentukan Industri Rumah Tangga}

Dalam pelaksanaan kegiatan Program Kemitraan Masyarakat (PKM) ini, proses pembentukan industri dilakukan dengan tujuan memberdayakan masyarakat khususnya kaum perempuan yaitu ibu-ibu rumah tangga dan remaja putri di Desa Tebat Monok dan Desa Talang Karet Kecamatan Kepahiang Kabupaten Kepahiang Provinsi Bengkulu sehingga dapat melakukan kegiatan ekonomi agar dapat mendukung kesejahteraan keluarga. Peran serta perempuan dapat memberikan kontribusi yang cukup besar. Beberapa fakta membuktikan bahwa perempuan yang bekrja mempunyai andil yang cukup besar dalam peningkatan perekonomian keluarga (Sofia, 2014).

Industri adalah kegiatan ekonomi yang mengolah bahan mentah, bahan baku, barang setengah jadi atau barang jadi menjadi barang dengan nilai yang lebih tinggi lagi penggunaannya, termasuk kegiatan rancang bangun industri dan perekayasaan industri (Kartasapoetra, 2000). Pemilihan jenis usaha dilakukan berdasarkan hasil diskusi dan kesepakatan bersama antara tim PKM dan mitra dengan tujuan terbentuknya industri kecil untuk menjual produk hasil karya masyarakat yang dikelola melalui wadah Pusat Kegiatan Belajar Masyarakat (PKBM) yaitu PKBM Alena Smart School untuk masyarakat Desa Tebat Monok dan PKBM Az-Zahir untuk masyarakat Desa Talang Karet. Spesifikasi usaha untuk masyarakat desa Tebat Monok difokuskan pada pembuatan handycraft dan handmade dengan merk dagang Tebat Monok Thonksys Galery \& Craft dan untuk masyarakat desa Talang Karet difokuskan pada pembuatan makanan olahan yaitu kue khas Bengkulu dengan merk dagang Talang Karet Thonksys Cake's. Merk dagang terdiri atas 3 (tiga) kata dengan makna sebagai berikut :

1. Kata Pertama adalah Nama desa yang mewakili masyarakat

2. Kata Kedua adalah Singkatan nama dari TIM PKM yang berdasarkan kesepakatan dengan mitra perlu dicantumkan karena merupakan penggagas dari usaha.

3. Kata ketiga adalah jenis usaha yang dirintis

Untuk nama PKBM dituliskan pada label kemasan, dimana pada label tertulis bahwa produk merupakan hasil karya masyarakat desa dibawah binaan PKBM. Hal ini dimaksudkan agar usaha yang telah dirintis dapat berkembang sejalan dengan tujuan PKBM sendiri sebagai pusat belajar masyarakat.

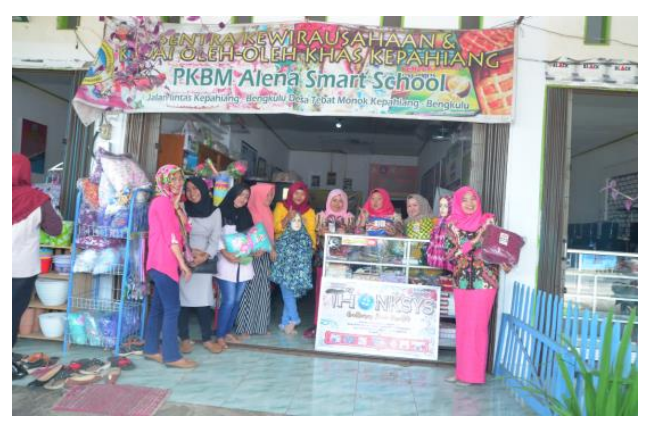

Gambar 1.Tampilan Usaha Produk Hasil Karya Masyarakat Desa Tebat 


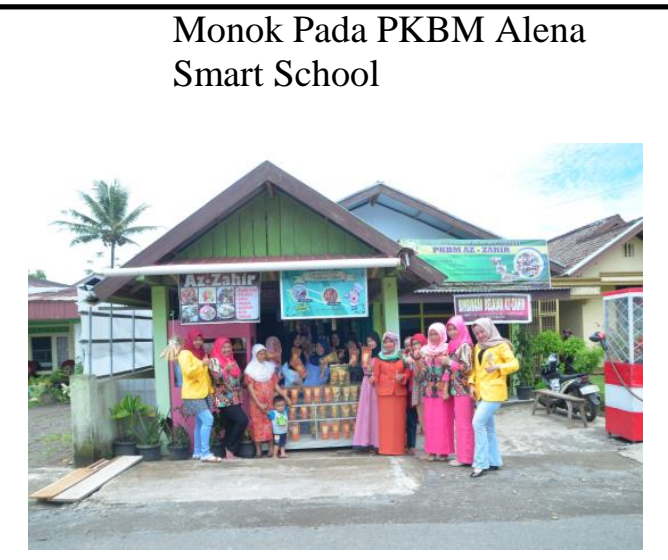

Gambar 2. Tampilan Usaha Produk Hasil Karya Masyarakat Desa Talang Karet Pada PKBM Az-Zahir

\section{Pelatihan dan Pendampingan Bidang Produksi}

Untuk menjaga efektifitas dan tercapainya tujuan kegiatan PKM, pelaksanaan pelatihan dan pendampingan produksi dilakukan secara terpisah yaitu untuk masyarakat Desa Tebat Monok dilaksanakan di PKBM Alena Smart School dan untuk masyarakat Desa Talang Karet akan dilaksanakan di PKBM AzZahir. Pelaksanaan kegiatan mendapat respon dan antusiasme yang tinggi. Dalam kegiatan ini juga melibatkan instruktur dari masing-masing PKBM sebagai pelaksana kegiatan. Kegiatan pelatihan dan pendampingan untuk masyarakat desa Tebat Monok difokuskan pada pembuatan handycraft dan handmade yaitu khimar batik, bantal, bros, dan rajutan. Sedangkan kegiatan Pelatihan dan Pendampingan untuk masyarakat desa Talang Karet difokuskan pada pembuatan makanan olahan yaitu kue khas Bengkulu cucur bandan dan kue tat.

Proses perancangan desain kemasan dilakukan melalui diskusi antara Tim PKM dan kedua mitra. Dalam proses perancangan desain label kemasan, kedua mitra memberikan masukan mengenai informasi inti meliputi jenis kemasan dan warna label, sedangkan Tim PKM dipercaya untuk mengembangkannya.
Label yang dibuat berbentuk stiker yang akan ditempelkan pada plastik atau kotak kemasan.

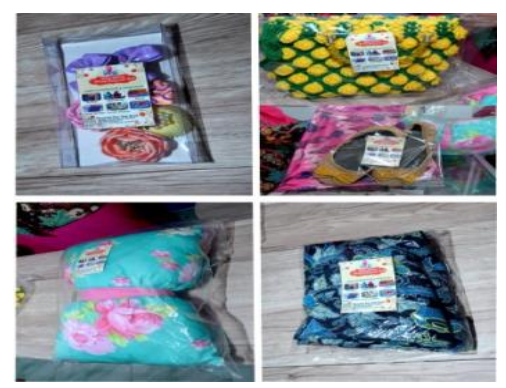

\section{Gambar 3. Produk Karya Masyarakat} Desa Tebat Monok

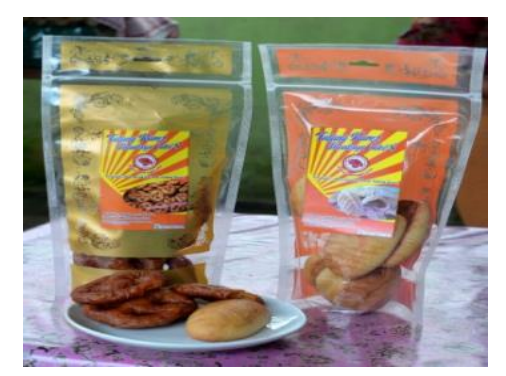

Gambar 4.Produk Karya Masyarakat Desa Talang Karet

\section{Pelatihan dan Pendampingan Bidang Manajemen dan Pemasaran}

Manajemen yang baik dalam suatu industri sangat menentukan keberhasilan dan keberlanjutan usaha. Dan kegiatan usaha harus diiringi dengan proses pemasaran yang baik sehingga diperoleh nilai ekonomi yang baik pula. Oleh karena itu, tim PKM bersama mitra sepakat untuk melakukan perancangan sistem manajemen keuangan dan pemasaran dalam usaha yang sedang dibangun.

Tim PKM melakukan pelatihan dan pendampingan untuk merancang sistem manajemen keuangan dan pemasaran secara terpisah yaitu untuk masyarakat Desa Tebat Monok di PKBM Alena Smart School dan untuk masyarakat Desa Talang Karet di PKBM Az-Zahir. Untuk pelatihan dan pendampingan manajemen, masyarakat diajarkan untuk membuat 
laporan keuangan usaha. Selain itu juga dilakukan pelatihan dan pendampingan dalam pengemasan produk.

Pada kegiatan pelatihan dan pendampingan pemasaran, hasil produksi masyarakat dipasarkan secara konvensional yaitu dipajang dengan etalase dan diberikan papan merk di depan PKBM agar masyarakat dapat mengetahui keberadaan produk. Masyarakat desa dapat menambah produk yang akan dijual dengan kreatifitas-kreatifitas yang lain dalam binaan PKBM, tidak hanya yang diajarkan pada kegiatan PKM. Tim PKM juga menggagas kegiatan pemasaran yang dilakukan secara online dalam bentuk promosi melalui media sosial yaitu Instagram. Berdasarkan hasil survey yang dilakukan oleh Asosiasi Penyelenggara Jaringan Internet Indoneisa (APJII) pada tahun 2016 menemukan bahwa 132,7 juta orang Indonesia telah terhubung ke internet dengan total penduduk Indonesia sebanyak 256,2 juta orang. Artinya $51,8 \%$ orang Indonesia telah terhubung ke Internet dan ini peluang besar untuk memasarkan tanpa ada sekat ruang dan waktu (Kompas, 2016). Sedangkan alasan pemilihan media instagram dikarenakan instagram banyak digunakan dalam kegiatan bisnis online dan kecenderungan masyarakat saat ini yang lebih suka mengakses instagram untuk melihat gambar atau video. Dalam kegiatan ini akan diinventarisir jenis-jenis informasi yang akan dimasukan ke media sosial tersebut meliputi nama produk, tampilan produk dan contact person. Tim PKM melakukan perancangan bentuk tampilan instagram untuk masing-masing usaha.

Setelah dilakukan kegiatan tersebut maka akan dipilih penanggungjawab untuk mengelola manajemen dan pemasaran untuk masing-masing usaha. Pemilihan disadarkan pada tingkat pendidikan, kemampuan operasional komputer, tingkat pemahaman terhadap materi yang disampaikan, dan aktifitas dalam kelompok. Keberadaan pengelola diharapkan mampu untuk memajukan usaha kedepan dan sebagai perpanjangan tangan antara masyarakat dengan PKBM.

\section{Pemberian Bantuan Peralatan}

Untuk mencapai tujuan utama dalam kegiatan PKM yaitu terbentuknya suatu usaha kecil masyarakat yang dikelola oleh PKBM, maka Tim PKM memberikan bantuan berupa peralatan inti yang diperlukan untuk kelancaran proses produksi seperti mesin jahit, mesin obras, etalase, patung untuk pajangan khimar, komputer, kursi plastik, meja lipat, peralatan pengolahan kue, sertabahan untuk menjahit, pembuatan handycraft dan handmade serta makanan olahan.

Selain memberikan bantuan untuk proses produksi, tim PKM juga memberikan bantuan untuk menunjang kegiatan pendidikan yaitu membantu mendesain ruangan yang nyaman untuk belajar dengan memanfaatkan potensi yang dimiliki PKBM agar kegiatan Paket A,B, dan $C$ yang dikelola oleh PKBM Alena Smart School dan kegiatan bimbingan belajar di PKBM Az-Zahir menjadi tempat yang menyenangkan untuk menimba ilmu.

Untuk meningkatkan minat baca dan mendukung kegiatan pendidikan di PKBM, maka juga didesain Taman Bacaan Masyarakat yang dilengkapi dengan bukubuku bacaan yang menarik dan bermanfaat. Taman bacaan masyarakat dapat dimanfaatkan oleh semua masyarakat Kepahiang bukan hanya untuk dua desa yang menjadi objek pengabdian.

Kegiatan pengabdian kepada masyarakat dalam bentuk pogram kemitraan masyarakat ini telah mencapai target yang diinginkan walaupun belum maksimal. Selain telah terbentuknya usaha kecil masyarakat, pengetahuan dan keterampilan masyarakat dalam menciptakan produk yang berkualitas dan bernilai jual juga meningkat. Terbukti dengan karya-karya yang lebih variatif dihasilkan oleh $80 \%$ masyarakat yang telah mengikuti pelatihan. Hal ini dilihat dari 
hasil produksi yang dipajang di etalase yang semakin hari semakin bertambah dan bervariasi.

Berdasarkan hasil wawancara dengan penanggungjawab di masingmasing usaha, saat ini 3-5 produk handycraft dan handmade hasil karya masyarakat terjual per hari di PKBM Alena Smart School. Dan 5-10 makanan olahan per hari di PKBM Az-Zahir dapat terjual. Hal ini tentu saja didukung oleh sistem manajemen dan pemasaran yang efektif dan efisien yang dilakukan baik secara langsung maupun melalui media sosial.

Dibidang pendidikan, berdasarkan hasil wawancara dengan pengelola PKBM, masyarakat yang putus sekolah telah banyak menggunakan fasilitas taman bacaan masyarakat, tidak hanya masyarakat peserta kegiatan namun masyarakat dari desa lain di kabupaten kepahiang juga telah memanfaatkan keberadaan taman bacaan masyarakat untuk mencari referensi atau sekedar membaca. Dan ini juga berdampak terhadap PKBM, dimana peserta kegiatan pendidikan kesetaraan atau paket dan bimbingan belajar meningkat sekitar $20 \%$. Hal ini tentu saja memberikan dampak positif bagi peningkatan kesejahteraan masyarakat dan perkembangan PKBM sebagai wadah pemberdayaan masyarakat.

\section{SIMPULAN}

Berdasarkan kegiatan PKM yang telah dilakukan, dapat ditarik kesimpulan sebagai berikut : 1) Telah terbentuk industri kecil dibawah binaan PKBM yang menjual produk hasil karya masyarakat desa dengan merk dagang yaitu Tebat Monok Thonksys Gallery\&Craft untuk masyarakat desa Tebat Monok di PKBM Alena Smart School dan Talang Karet Thonksys Cake's untuk masyarakat desa Talang Karet di PKBM Az-Zahir yang dipasarkan secara langsung di PKBM dan juga melalui media sosial instagram.2) Bertambahnya pengetahuan dan keterampilan masyarakat sehingga dapat menghasilkan produk yang berkualitas dan bernilai jual. Produk yang dihasilkan oleh masyarakat desa Tebat Monok difokuskan pada pembuatan handycraft dan handmade seperti khimar batik, bantal, bros, dan lain sebagainya. Sedangkan produk yang dihasilkan oleh masyarakat desa Talang Karet difokuskan pada pembuatan makanan olahan seperti kue cucur bandan, kue tat dan makanan olahan lainnya. 3) Peningkatan kualitas dibidang pendidikan dengan desain ruangan yang lebih nyaman dan didukung oleh adanya taman bacaan masyarakat agar pengetahuan masyarakat lebih meningkat.

\section{UCAPAN TERIMAKASIH}

Terimakasih Kepada Direktorat Riset dan Pengabdian Kepada Masyarakat Kemenristek Dikti Atas Dana Hibah Program Kemitraan Masyarakat Tahun 2018

\section{DAFTAR PUSTAKA}

Campobasso, L and D Davis, (2001). Reflection on Capacity Building, the California Wellness Foundation Journal, 2, (2).

Departemen Pendidikan Nasional. (2003). Undang-Undang Nomor 20 Tahun 2003 Tentang Sistem Pendidikan Nasional. Jakarta: Depdiknas

Irmawati, A., (2017). Peran PKBM Dalam Mengurangi Buta Aksara Di Kabupaten Karimun. Jurnal Pendidikan dan Kebudayaan, 2 (1).

Jalal, F., (2004). Membangun Pusat Kegiatan Belajar Masyarakat. Jakarta: Direktorat Jendral

Kompas. (2016). Pengguna Internet Di Indonesia Capai 132 Juta. http://tekno.kompas.com/read/2016/10 /24/15064727/2016.pengguna.internet. di.indonesia.capai.132.juta. (Diakses Pada 27 April 2018)

Kuncoro, M., (2006). Usaha Kecil Di Indonesia : Profil, Masalah, dan Strategi Pemberdayaan. Journal 


Usaha Kecil Indonesia.
http//www.cyberax.eu/book/1843143
(Diakses Pada 27 Mei 2017)

Sihombing, (2001). Pendidikan Luar Sekolah; Masalah, Tantangan Dan Peluang. Jakarta: Wirakarsa

Sofia, R.N. (2014). Peran Perempuan Dalam Keluarga Islami. sofia_psy.staf.ugm.ac.id (Diakses Pada 27 April 2018)

Sumpeno, W., (2009). Sekolah Masyarakat : Penerapan Rapid - Training Design Dalam Pelatihan Berbasis Masyarakat. Yogyakarta: Pustaka Pelajar

Sutisna, Firmasyah D., et al. (2012). Peranan PKBM Dalam menumbuhkan Minat Baca Warga Belajar. Students e-Journal. 1 (1)

Yulaelawati, E. (2010). Kurikulum dan Pembelajaran. Bandung: Pakar Raya

Undang-Undang Nomor 3 Tahun 2014 Tentang Perindustrian Lembaran Negara Republik Indonesia Tahun $2014 \quad$ Nomor 4. www.ppi.kemenperin.go.id (Diakses Pada 27 Mei 2017)

Profil PKBM Alena Smart School

Profil PKBM Az-Zahir 